\title{
The Impact of Post-Manufacture Treatments on the Surface Characteristics Important for Finishing of OSB and Particleboard
}

\author{
Antonio Copak, Vlatka Jirouš-Rajković, Nikola Španić (i) and Josip Miklečić *(i) \\ Department of Wood Technology, Faculty of Forestry and Wood Technology, Institute of Furniture and Wood \\ Products, 10000 Zagreb, Croatia; acopak@sumfak.unizg.hr (A.C.); vjirous@sumfak.unizg.hr (V.J.-R.); \\ nspanic@sumfak.unizg.hr (N.Š.) \\ * Correspondence: jmiklecic@sumfak.unizg.hr; Tel.: +385-1-2352-536
}

check for

updates

Citation: Copak, A.; Jirouš-Rajković, V.; Španić, N.; Miklečić, J. The Impact of Post-Manufacture Treatments on the Surface Characteristics Important for Finishing of OSB and

Particleboard. Forests 2021, 12, 975. https://doi.org/10.3390/f12080975

Received: 31 May 2021

Accepted: 19 July 2021

Published: 22 July 2021

Publisher's Note: MDPI stays neutral with regard to jurisdictional claims in published maps and institutional affiliations.

Copyright: (C) 2021 by the authors. Licensee MDPI, Basel, Switzerland. This article is an open access article distributed under the terms and conditions of the Creative Commons Attribution (CC BY) license (https:// creativecommons.org/licenses/by/ $4.0 /)$.

Abstract: Oriented strand board (OSB) is a commonly used structural wood-based panel for walls and roof siding, but recently the industry has become interested in OSB as a substrate for indoor and outdoor furniture. Particleboard is mainly used in furniture productions and has become popular as a construction material due to its numerous usage possibilities and inexpensive cost. Moisture is one of the most important factors affecting wood-based panel performance and the post-treatment conditions affected their affinity to water. When OSB and particleboard are used as substrates for coatings, their surface characteristics play an important role in determining the quality of the final product. Furthermore, roughness can significantly affect the interfacial phenomena such as adsorption, wetting, and adhesion which may have an impact on the coating performance. In this research particleboard and OSB panels were sanded, re-pressed and IR heated and the influence of surface treatments on hardness, roughness, wetting, water, and water vapour absorption was studied. Results showed that sanding improved the wetting of particleboard and OSB with water. Moreover, studied surface treatments increased water absorption and water penetration depth of OSB panels, and re-pressing had a positive effect on reducing the water vapour absorption of particleboard and OSB panels.

Keywords: OSB; particleboard; contact angle; roughness; water absorption; water vapour absorption

\section{Introduction}

Oriented strand board (OSB) is a structural reconstituted panel that consists of wood strands glued with resin. In the last decade, OSB has gained significant growth in the structural wood-based panel market [1]. OSB is commonly used structural wood-based panel for walls and roof siding, but recently the industry has become interested in OSB as a substrate for indoor and outdoor furniture [2]. Furniture made of boards are technologically easy to mass-produce and susceptible to the use of typical fastener joining methods [3]. It can be manufactured from either hardwoods or softwood, or from a mix of both. Typical OSB is composed of three separately oriented layers of strands of which the top and bottom surface layers are oriented with the long strand axis and a grain direction parallel to the length of the panel, and the centre or core layer is oriented $90^{\circ}$ to the top layers, with the long strand axis parallel to the width of the panel [4].

Particleboard is manufactured by mixing wood chips or wood particles with a suitable resin, followed by compressing the glued bonded wood chips. They differ significantly from each other in terms of the amount and types of resins used, the size and geometry of the particles, as well as the density of particleboard. Particleboard is mainly used in furniture productions and has become popular as a construction material due to its numerous usage possibilities and inexpensive cost [5].

Moisture is one of the most important factors affecting wood-based panel performance [4] and moisture changes affect mating the wooden elements [6]. Water absorption 
of particleboard is strongly related to their specific mass [7]. If a board mass is lower, there are more free spaces in its structure and, consequently, the water absorption is higher. However, this mostly regards particleboard that has not undergone any additional post-treatment. If the panels are subjected to various heat post-treatments, their water absorption becomes affected by the post-treatment conditions, with temperature being highlighted as the main factor influencing the wood hygroscopicity $[8,9]$. The influence of heat pre- or post-treatments on the dimensional stability, biological durability, and mechanical properties of particleboard is studied extensively [10-16]. However, the effects of heat post-treatments on particleboard water absorption are studied far less than the extensively studied influence on boards' thickness swelling. The results of studying the effect of thermal rectification of particleboard reveal that the dimensional stability and water absorption of particleboard are mostly related with the degradation of hemicelluloses $[17,18]$ as they thermally decompose at a relatively low temperature, well below $350{ }^{\circ} \mathrm{C}$ [19]. Additional reasons for water absorption change could be associated with the extractives volatilization [20], the occurrence of an in situ plastic flow if boards are heated above the temperature of lignin and carbohydrate softening point [21], lignin structure modification and rearrangement due to high temperatures used for thermal rectification [22] and aforementioned specific mass or mass loss during heat post-treatment [23]. Therefore, the main reasons for heat post-treated particleboard water absorption changes are strongly related to the modification in physical properties of wood from which they were made, and which is more pronounced in case of higher rectification temperatures [24]. This is also governed by the rectification process itself, as it was found that the water absorption of particleboard is, for instance, improved more by applying the hot oil treatment than the dry heat treatment [25].

Direct surface finishing (coating or painting) of wood-based panel surfaces requires increasing emphasis on surface quality. Good surface quality facilitates the application of coating materials and reduces the cost of finishing operations [26]. The objectives of sanding wood elements are to achieve the surface properties to be coated or glued, and required shape or dimensional accuracy [27]. When OSB and particleboards are used as substrates for coatings their surface characteristics, such as roughness, play an important role in determining the quality of the final product. In addition to the appearance of the product, roughness can significantly affect the interfacial phenomena such as adsorption, wetting, and adhesion which may have an impact on the coating (finishes) performance. The rough surface gives paints possibilities to penetrate the surface and can help in the anchorage of the paint. However, very high roughness can have negative effect such as high cost due to a large amount of paint necessary to achieve a smooth appearance. It has been established that the higher values of roughness of uncoated particleboard lead to thinner coating films on the surface [28]. There is no standard metrology for the evaluation of the surface roughness of wood-based panels [29,30]. Many authors use the stylus method to evaluate the surface roughness of particleboard [28,30-37] and several authors used the stylus method for OSB $[2,37,38]$. The surface roughness of wood-based panels depends on raw material properties and production processes [34,39]. Surface sanding has proven to be a useful operation before applying the coating material as it levels off inherent differences in wood surface properties, resulting in an equal and homogeneous spread of coating material [40]. It has also been identified that spreading rates of coating materials and surface roughness are related, and that rough surface substrates need more finish coverage per area than smooth surface substrates [40]. Sanding factors were found to have a significant effect on the surface roughness of the particleboard [34]. It was also found that fine abrasive sanding reduced the average roughness of OSB, but had a smaller effect on maximum roughness, as sanded boards still contained surface voids between strands [41]. Additionally, sanded boards absorbed less than half of the coating material of unsanded boards. Del Menezzi et al. [38] studied the effect of thermal post-treatment on the roughness of OSB using two temperature levels $\left(190^{\circ} \mathrm{C}\right.$ and $\left.220^{\circ} \mathrm{C}\right)$ during 12,16 , and $20 \mathrm{~min}$. They found reduced values of roughness parameters $\mathrm{Ra}, \mathrm{Rq}$, and $\mathrm{Rz}$ for the 
treatments $\mathrm{T} 2\left(190{ }^{\circ} \mathrm{C}\right.$ and $\left.16 \mathrm{~min}\right)$ and $\mathrm{T} 4\left(220^{\circ} \mathrm{C}\right.$ and $\left.12 \mathrm{~min}\right)$. Unsal et al. [37] showed that thermal modification of OSB improved surface roughness parameters of all treated panels compared to untreated. The lowest Ra value was determined for panels treated with $210^{\circ} \mathrm{C}$ for $1 \mathrm{~h}$.

The main objective of this paper is to investigate the impact of post-manufacture treatments (surface sanding, re-pressing, and IR heating) on the surface characteristics (hardness, roughness, wetting, surface free energy, water, and water vapour absorption) important for finishing commercially manufactured OSB and particleboard.

\section{Materials and Methods}

\subsection{Materials}

In this study, two types of wood-based panels commercially available on the market were used: oriented strand board (OSB) type 3 and three-layer particleboard E1. The basic properties of the tested panels are presented in Table 1 . Twelve samples of dimensions $400 \times 400 \mathrm{~mm}$ for each panel type were conditioned for one month at $23 \pm 2{ }^{\circ} \mathrm{C}$ and $50 \pm$ $5 \%$ RH. After conditioning, the surface of the samples was prepared with four different treatments (Table 2). For each surface treatment, three samples of OSB and particleboard were selected.

Table 1. Properties of tested wood-based panels.

\begin{tabular}{ccccc}
\hline Type of Board & Type of Resin & $\begin{array}{c}\text { Density } \\
\left(\mathbf{g} / \mathbf{c m}^{\mathbf{3}}\right)\end{array}$ & $\begin{array}{c}\text { Moisture Content } \\
(\mathbf{\%})\end{array}$ & $\begin{array}{c}\text { Thickness } \\
(\mathbf{m m})\end{array}$ \\
\hline OSB & $\mathrm{pMDI}^{1}$ & 0.6033 & 7.9 & 12 \\
Particleboard & $\mathrm{UF}^{2}$ & 0.6479 & 7.4 & 12 \\
\hline
\end{tabular}

${ }^{1}$ Polymeric diphenylmethane diisocyanate. ${ }^{2}$ Urea-formaldehide.

Table 2. Parameters of surface treatments.

\begin{tabular}{cc}
\hline Type of Surface & Process Parameters \\
\hline Raw & Commercial board prepared in factory \\
Pressed & Press time: 3 min, pressure: $0.8 \mathrm{MPa}$, temperature: $120^{\circ} \mathrm{C}$ \\
Sanded & 1. step: sanding with sandpaper P80 grit-size \\
Heated & 2. step: sanding with sandpaper P120 grit-size \\
& (average thickness of sanded layer: OSB $=0.65 \mathrm{~mm}$, particleboard $=0.32 \mathrm{~mm})$ \\
Heated with IR heater until surface of sample reached $50^{\circ} \mathrm{C}$
\end{tabular}

\subsection{Brinell Hardness}

Brinell hardness was carried out according to standard EN 1534:2020 [42] with universal testing machine Shimadzu AG-X only on raw and re-pressed panels as sanding and heating of the panels did not affect the surface hardness of OSB and particleboard. Before testing, panels were conditioned for one week at $23 \pm 2{ }^{\circ} \mathrm{C}$ and $50 \pm 5 \% \mathrm{RH}$. On every sample, 25 measurements were made, and the average value was calculated.

\subsection{Wetting Angle and Surface Free Energy}

The dispersive and polar component of surface free energy of OSB and particleboard were determined by contact angle goniometer instrument OCA 20, DataPhysics Instruments at a temperature of $23^{\circ} \mathrm{C}$. Calculations of panels' surface free energies were performed using contact angles of water, formamide, and diiodomethane at samples dimensions of $50 \times 100 \mathrm{~mm}$ at five locations per sample. Diiodomethane was chosen as a nonpolar test liquid to avoid problems due to the polarity of wood [43]. Dispersive and polar components of surface free energies of test liquids are: water $\left(\gamma=72.8 \mathrm{~mJ} / \mathrm{m}^{2}, \gamma \mathrm{d}\right.$ $\left.=21.8 \mathrm{~mJ} / \mathrm{m}^{2}, \gamma \mathrm{p}=51.0 \mathrm{~mJ} / \mathrm{m}^{2}\right)$, formamide $\left(\gamma=58.0 \mathrm{~mJ} / \mathrm{m}^{2}, \gamma \mathrm{d}=39.0 \mathrm{~mJ} / \mathrm{m}^{2}, \gamma \mathrm{p}=\right.$ $\left.19.0 \mathrm{~mJ} / \mathrm{m}^{2}\right)$ and diiodomethane $\left(\gamma=50.8 \mathrm{~mJ} / \mathrm{m}^{2}, \gamma \mathrm{d}=50.8 \mathrm{~mJ} / \mathrm{m}^{2}, \gamma \mathrm{p}=0 \mathrm{~mJ} / \mathrm{m}^{2}\right)$ [44]. The contact angle between a liquid drop and the tested sample was determined $10 \mathrm{~s}$ after 
the application of the liquid drop. From the measured values of contact angles and the known values of the surface free energy for the test liquids dispersive and polar components of the surface free energy were calculated according to OWRK [45] model using software SCA 21 [46].

\subsection{Surface Roughness}

Roughness measurements were performed on a surface of five identically prepared OSB and particleboard samples dimension of $50 \times 50 \mathrm{~mm}$. On each sample, three profiles were recorded using Mitutoyo SJ-500 instrument equipped with a $10 \mu \mathrm{m}$ stylus tip radius and $90^{\circ}$ tip angle at a speed of $0.5 \mathrm{~mm} / \mathrm{s}$. The profiles were spaced by a minimum of $15 \mathrm{~mm}$. The used cut-off was $2.5 \mathrm{~mm}$ with a sapling length of $17.5 \mathrm{~mm}(7 \times 2.5 \mathrm{~mm})$. To detect a difference in the roughness of differently prepared surfaces, the following parameters were calculated: Ra, Rz, Rt, Rv, Rsk, and Rsm. Ra is probably the most used parameter for estimating surface roughness. This parameter represents an arithmetic mean deviation of the assessed profile and is used as a global evaluation of the roughness amplitude on a profile. Surface irregularities that are not clearly noticed by the Ra parameter can be detected using the height parameters ( $\mathrm{Rz}, \mathrm{Rt}$, and $\mathrm{Rv})$ and the shape parameter Rsk [30]. $\mathrm{Rz}$ is the average maximum peak to valley of five consecutive sampling lengths within the measuring length and offers an advantage over parameter Rt, as it incorporates more of the surface. Rt is the height of the single "tallest" peak to the depth of the "deepest" valley within an evaluation length. $R v$ is defined as the distance between the mean line and the lowest valley. The Rsk parameter gives information on the morphology of the surface texture. Positive values correspond to high peaks spread on a regular surface (distribution skewed towards bottom) while negative values are found on surfaces with pores and scratches (distribution skewed towards top) [47]. The RSm parameter measures the surface irregularities in a horizontal direction: the larger the irregularities, the higher the RSm value [30].

\subsection{Water and Water Vapour Absorption}

Six samples of OSB and particleboard with an identically prepared surface of dimensions $150 \times 74 \mathrm{~mm}$ were prepared from the large surface treated and untreated panels. The sides and back of the sawn samples were sealed with two coats of $2 \mathrm{k}$ epoxy coating to ensure measurement of water and water vapour absorption only on the test surface. Sealed samples were conditioned for 28 days at $23 \pm 2{ }^{\circ} \mathrm{C}$ and $50 \pm 5 \% \mathrm{RH}$. After the condition, three samples for each surface treatment and panel type were placed on the water with the test surface facing down to measure water absorption and three samples for each surface treatment and panel type were exposed to $98 \%$ air humidity to measure water vapour absorption. For water absorption, samples were weighed before immersion and during immersion in water, every $24 \mathrm{~h}$ for the next 7 days. For water vapour absorption samples were weighed before exposure and after 7 and 14 days of exposure to high humidity.

\subsection{Water Penetration}

For measuring the depth of water penetration into the tested OSB and particleboard samples the dye with Rhodamine B was prepared (1\% water solution of Rhodamine B dissolved in acetic acid). On the surface of tested panel samples, $3 \mathrm{~mL}$ of prepared dye was applied and left for $24 \mathrm{~h}$. The dye was covered with a watch glass to prevent evaporation and spillage of the solution over the edges of the sample. After $24 \mathrm{~h}$, the watch glass was removed, and the excess solution of dye was washed with distilled water. The samples, thus prepared, were dried in an oven for $4 \mathrm{~h}$ at $80^{\circ} \mathrm{C}$ to evaporate any unwashed acetic acid from the surface. After drying, the samples were sawed with a band saw exactly through the middle of the Rhodamine staining trace. The cutting (side) surface was observed with a digital UV microscope with a magnification of $30 \times$ and water penetration depth was measured. 


\section{Results and Discussion}

In severe end-use surface, hardness plays an important role [38]. The results showed that Brinell hardness was increased after re-pressing of the particleboard and OSB samples, but only the increase in particleboard surface hardness is statistically significant (Table 3).

Table 3. Brinell hardness of raw and re-pressed samples.

\begin{tabular}{cccc}
\hline Type of Sample $^{\mathbf{1}}$ & Brinell Hardness & Standard Deviation & $\boldsymbol{p}$-Value \\
\hline PB & 3.62 & 0.705 & \\
PB-P & 4.67 & 1.501 & $0.010786^{*}$ \\
OSB & 3.85 & 1.528 & \\
OSB-P & 4.39 & 0.567 & 0.356742 \\
\hline
\end{tabular}

${ }^{1}$ PB: raw particleboard, PB-P: re-pressed particleboard, OSB: raw oriented strand board, and OSB-P: re-pressed oriented strand board. * Difference statistically significant in comparison with raw particleboard or OSB panel according to the Dunnett test at $\alpha=0.05$ significance level.

According to the literature, the increase in surface hardness of OSB is related to the densification of boards after re-pressing at high temperature [48] and hardness is positively correlated with the density of the wooden materials [49]. Furthermore, re-pressing of particleboard at high temperatures causes changes in the physical properties, especially of panel density. Lee et al. [50] reported that Brinell hardness of particleboard increased after hot press at $100{ }^{\circ} \mathrm{C}$ and $150^{\circ} \mathrm{C}$.

The values of the contact angle of water were quite high on particleboard and OSB, due to a large amount of resin on the panel surface (Figure 1). Therefore, wetting of the particleboard and OSB surface with water improved when the surface layer of resin was removed with sanding. Improving the wetting of the particleboard and OSB surface with water after sanding can have a significant impact on improving the adhesion of water-based coatings. Re-pressing at a temperature of $120^{\circ} \mathrm{C}$ and heating at $50{ }^{\circ} \mathrm{C}$ had no significant effect on the wetting of particleboard and OSB surfaces with water, formamide, and diiodomethane. According to the literature, temperatures above $150{ }^{\circ} \mathrm{C}$ cause an increase in water contact angle on OSB [37].

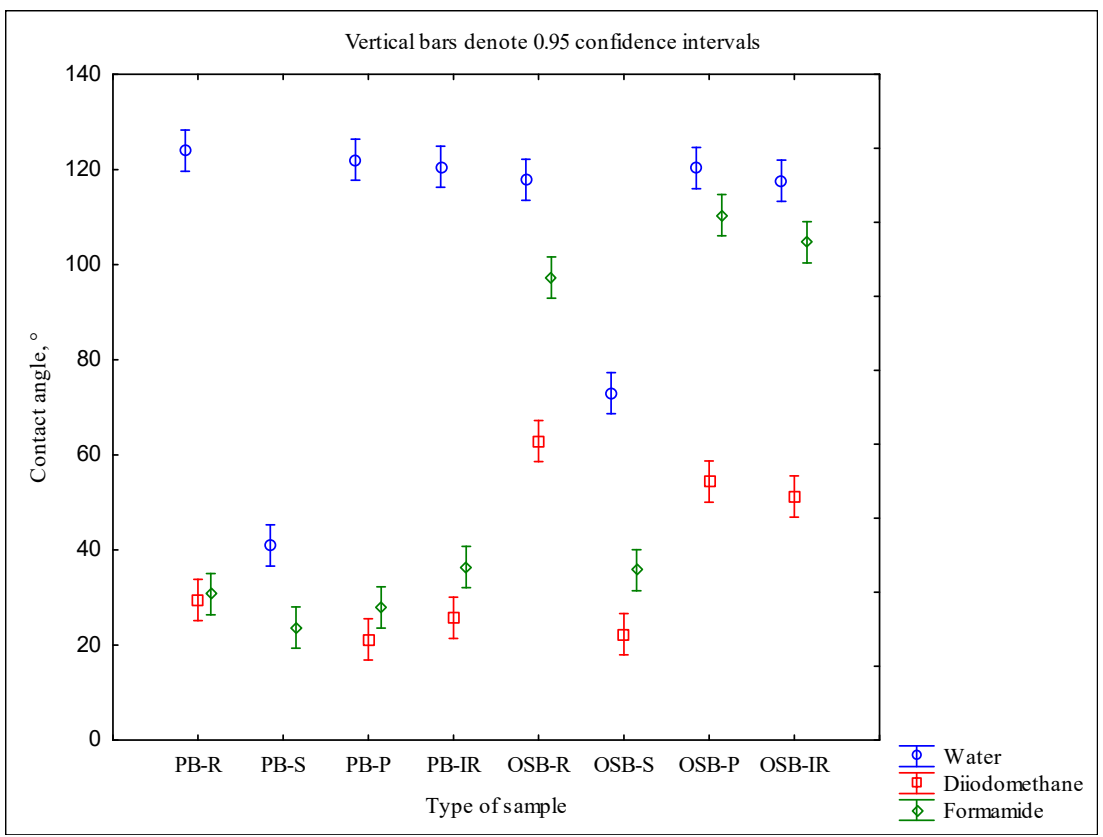

Figure 1. Contact angle of water, diiodomethane and formamide on particleboard and OSB samples (PB-R: raw particleboard, PB-S: sanded particleboard, PB-P: re-pressed particleboard, PB-IR: heated particleboard, OSB-R: raw OSB, OSB-S: sanded OSB, OSB-P: re-pressed OSB, and OSB-IR: heated OSB). 
Wettability of particleboard and OSB surface by water as polar solvents was generally lower than wettability by a diiodomethane as a nonpolar solvent. The same result was obtained by Gérardin et al. [51] at solid beech and pine wood. The largest difference in the contact angle values between particleboard and OSB is visible on formamide. It can be seen that the contact angle of formamide on raw, re-pressed and heated OSB is more than twice as large as on particleboard. This indicates that the interaction of formamide with UF resin on particleboard is different from the interaction of formamide with pMDI resin on OSB. Additionally, the wetting of wood is influenced by macroscopic characteristics (porosity, surface roughness, surface polarity, $\mathrm{pH}$, moisture content, grain orientation, and extractives) and surface quality (virgin, ageing, or contamination) [52].

The results of surface free energy with a dispersive and polar component on particleboard and OSB are presented in Figure 2. Knowing the surface energy of wood can help in understanding the wetting and adhesion of coatings to wood. De Meijer et al. [53] found that the SE of wood ranges from $30 \mathrm{~mJ} / \mathrm{m}^{2}$ to $50 \mathrm{~mJ} / \mathrm{m}^{2}$. It can be seen that the SE of particleboard is higher than SE of OSB, regardless of the surface treatment. Sanding had the greatest effect on the change of SE of tested panels, on particleboard the sanding reduced SE and on OSB the sanding increased SE.

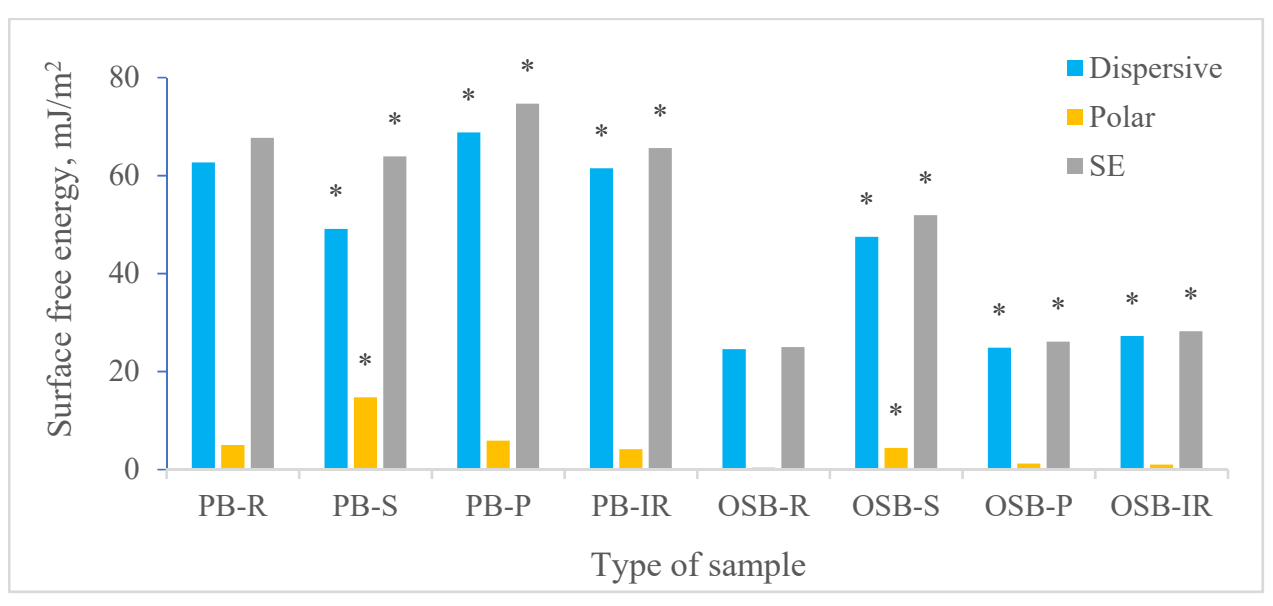

Figure 2. Surface free energy with a dispersive and polar component on particleboard and OSB samples (PB-R: raw particleboard, PB-S: sanded particleboard, PB-P: re-pressed particleboard, PB-IR: heated particleboard, OSB-R: raw OSB, OSB-S: sanded OSB, OSB-P: re-pressed OSB, and OSB-IR: heated OSB). * Difference statistically significant in comparison with raw particleboard or OSB panel according to the Tukey test at $\alpha=0.05$ significance level.

To optimize wetting of the wood surface with a coating, SE of wood should be higher than the surface tension of the coating. Furthermore, markedly lower values of the polar component than the dispersive component of SE on particleboard and OSB indicate that the polar liquids will poorly wet the surface of the particleboard and OSB, which may result in poorer adhesion.

The surface roughness measurement results are presented in Table 4. It can be seen that particleboard exhibited higher values of all roughness parameters than OSB. The only exception is the higher Rt parameter on the raw OSB board and the re-pressed OSB board. The roughness measurement results on OSB should be taken with a reservation, as the structure of the panel itself strongly influences the results and they can largely depend on the measurement location on the board. As can be seen from Table 4, the roughness values of OSB are spread out in a wider range than the roughness values of particleboard, which can be seen from the values of standard deviations. Moreover, all roughness parameters of OSB were reduced after sanding, as expected. 
Table 4. Results of roughness measurements on OSB and particleboard.

\begin{tabular}{ccccc}
\hline \multicolumn{5}{c}{ OSB } \\
$\begin{array}{c}\text { Roughness } \\
\text { Parameter }\end{array}$ & Raw & Sanded & Re-Pressed & IR-Heated \\
\hline$R a$ & $7.27(2.69)^{1}$ & $5.59(2.25)$ & $7.48(4.30)$ & $5.59(2.75)$ \\
$R z$ & $53.13(20.50)$ & $44.64(14.64)$ & $55.09(28.73)$ & $40.54(18.15)$ \\
$R t$ & $111.00(51.11)$ & $88.01(37.62)$ & $125.80(86.38)$ & $86.30(49.91)$ \\
$R v$ & $36.95(15.73)$ & $28.67(11.02)$ & $38.01(18.46)$ & $27.28(11.46)$ \\
$R s k$ & $-0.93(0.49)$ & $-0.80(0.53)$ & $-1.15(0.37)$ & $-1.00(0.20)$ \\
$R S m$ & $223.76(90.32)$ & $133.59 *(41.95)$ & $165.88(105.43)$ & $145.44 *(31.42)$ \\
\hline & & Particleboard & & \\
\hline Roughness & Raw & Sanded & Re-Pressed & IR-Heated \\
Parameter & & & $7.68(1.31)$ & $11.22 *(1.8)$ \\
$R a$ & $8.21(1.06)$ & $8.24(0.85)$ & $54.93(7.72)$ & $78.43 *(11.14)$ \\
$R z$ & $57.90(7.98)$ & $63.61(7.83)$ & $87.12(19.09)$ & $119.24 *(22.54)$ \\
$R t$ & $85.11(18.87)$ & $96.07(18.91)$ & $39.81(6.06)$ & $53.75(8.52)$ \\
$R v$ & $39.09(6.39)$ & $46.44(7.66)$ & $-1.28(0.24)$ & $-1.08(0.21)$ \\
$R s k$ & $-1.04(0.23)$ & $-1.51 *(0.33)$ & $178.08(23.05)$ & $237.25 *(28.31)$ \\
$R S m$ & $171.49(21.06)$ & $198.09(23.86)$ & & \\
\hline
\end{tabular}

${ }^{1}$ SD in parentheses. ${ }^{*}$ Difference statistically significant in comparison with raw panel according to the Tukey test at $\alpha=0.05$ significance level.

On the contrary, all measured roughness parameters of particleboard except the parameter Ra were increased after sanding treatment. These differences of roughness values before and after sanding on particleboard were not significant, but were unexpected. A more detailed microscopic analysis of the surfaces before and after sanding showed that small cavities related to wood-dust resin spots appeared on the surface of particleboard after sanding (marked with an arrow in Figure 3B).
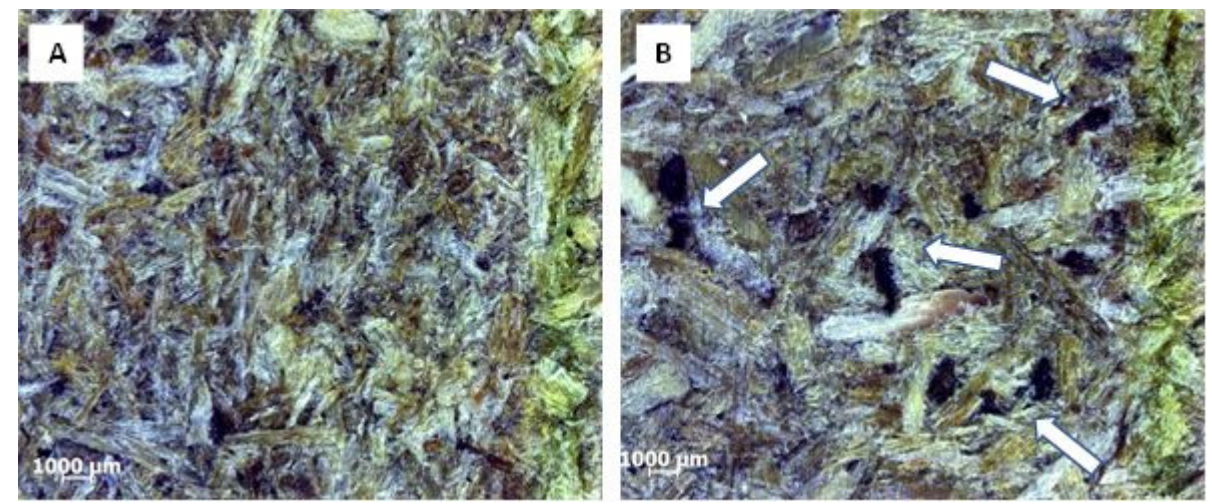

Figure 3. Micrographs of raw (A) and sanded (B) surface of particleboard at $40 \times$ magnification.

Wood dust-resin spots are unavoidable in commercial particleboard production, as the specific area of wood dust particles is rather large thus leading to the formation of unfavourable agglomerates of dust-covered with an extensive amount of glue (resin) mixture. Wood dust particles are, however, required in industrial particleboard production, as they fill the gaps between individual particles (strands) of the outer layer, thus contributing greatly to the formation of water diffusion barrier [54,55]. IR heating treatment of particleboard caused an increased value of all roughness parameters (except Rsk) compared to roughness of raw particleboard. The differences are significant for the parameters $\mathrm{Ra}, \mathrm{Rz}$ and Rt, and Rsm. It is possible that, due to the heating at $50{ }^{\circ} \mathrm{C}$, moisture evaporated from the core layers to the surface layers, which caused an increase in roughness. The roughness measurements result of re-pressed particleboard are not so clear as some parameters after 
re-pressing were reduced ( $\mathrm{Ra}$ and $\mathrm{Rz}$ ) and some parameters were almost unchanged (Rt, $\mathrm{Rv}$, and Rsm) compared to row particleboard. In contrast, almost all roughness parameters of re-pressed OSB (except Rsm) were higher compared to raw OSB, but these differences were not statistically significant. This increase in roughness could be caused by water escaping from the inner layers to the surface of OSB due to the re-pressing process. In addition, IR treatment reduced the surface roughness of OSB compared to the untreated surface, but the differences in values were also not significant.

The results of water absorption for particleboard and OSB, depending on the exposure time and surface treatment of the panel, are given in Figure 4. Apart from the fact that the water absorption of each of the examined test samples groups rose with the extension of the time of exposure, additional conclusions could be made. Sanding of particleboard and OSB samples increased water absorption, which is almost certainly the result of permanent removal of protective, hydrophobic (wax) layer from the surface of test samples, accompanied with complete removal of wood dust-resin spots from the particleboard surface (Figure 3B). The pressure of $0.8 \mathrm{MPa}$ is not enough to cause a major increase in density of tested particleboard and OSB $(0.3 \%$ on average) and consequent reduction in water absorption. Therefore, the increase in water absorption of particleboard and OSB after re-pressing can be also related to the removal of a protective, hydrophobic (wax) layer from the surface caused by a high temperature $\left(120^{\circ} \mathrm{C}\right)$ during re-pressing.

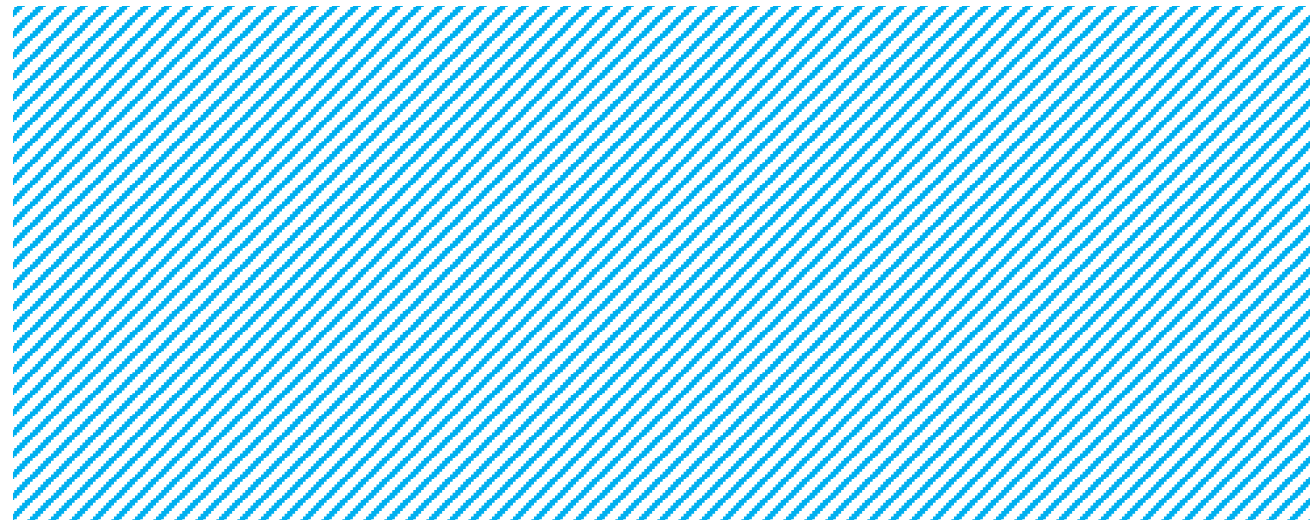

Figure 4. Water absorption of tested particleboard and OSB panels after 1 and 7 days of immersion in water. ${ }^{*}$ Difference statistically significant in comparison with raw particleboard or OSB panel according to the Tukey test at $\alpha=0.05$ significance level.

The mass of test samples rose when samples were subjected to IR heating ( $1.5 \%$ for OSB and $1.9 \%$ for particleboard) and it decreased when they were re-pressed ( $10.6 \%$ for OSB and 2.3\% for particleboard). Such tendencies indicate that the water contents and the hydrophylicity of the outermost layers of individual strands on particleboard and OSB surfaces were altered depending on the heating method. As IR light treatment implies focused heating of boards' surfaces, partial lignin degradation probably also occurred [56]. Lignin is a hydrophobic polymer, and its degradation changed the surface chemistry and led to a slight mass increase due to the rise of surface hydrophilicity. Contact heating of test samples in the hot press caused not only the lignin degradation, but also water loss from the boards' structure. Relations between water absorption of re-pressed and IR heated samples could therefore be associated with the extent of lignin degradation and water loss.

The results of water vapour absorption for particleboard and OSB, as a dependant of exposure time and surface treatment of the panel, are given in Figure 5. As can be seen, the water vapour absorption values rise with the extension of exposure time which is similar to the water absorption results. Density increase, as a result of re-pressing of test samples, resulted in the water vapour absorption decline in particleboard and OSB compared to the values obtained for raw panels. Furthermore, the water vapour absorption results reveal that the sanding had a greater impact on OSB than on particleboard, regardless of the exposure time. 


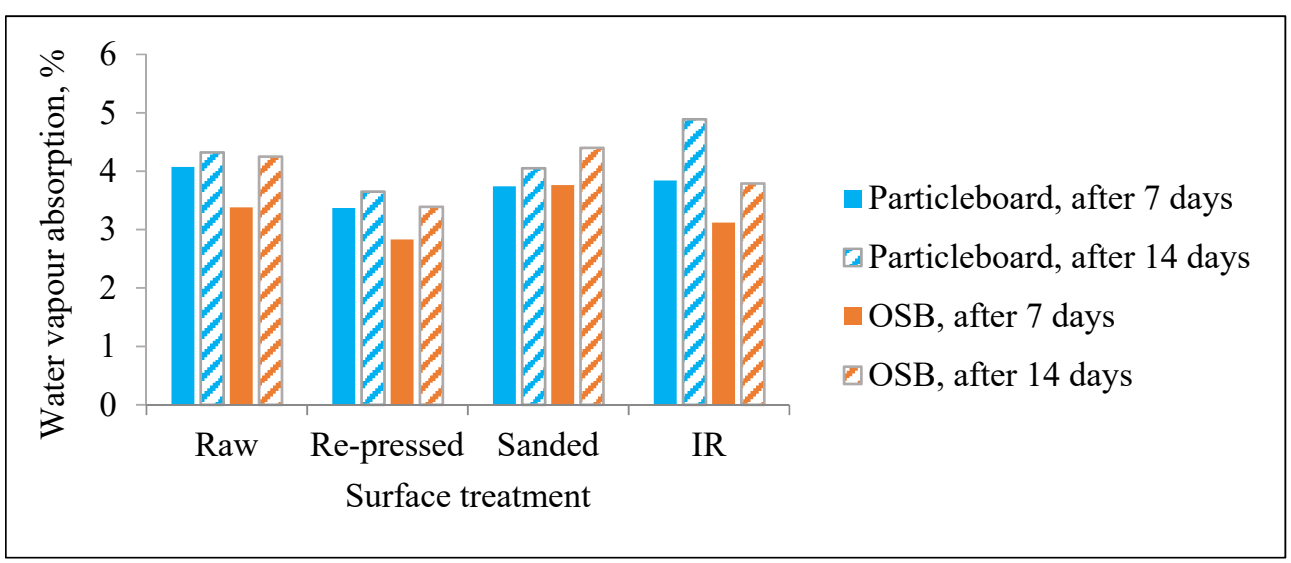

Figure 5. Water vapour absorption of tested particleboard and OSB panels after 7 and 14 days of exposure to high humidity. No statistically significant difference was found between surface treatments and raw panels.

The results also reveal that the differences between the water vapour absorption values obtained after 7 and 14 days, in all the examined cases are less than $1.0 \%$. Those differences could be associated with the small changes of surface hydrophylicity due to the mechanical removal of hydrophobic wax barrier (OSB) and lignin degradation (particleboard) as it is known that, in wood, most sorption sites are found in the hemicelluloses followed by cellulose and lignin [57]. However, sorption processes (water absorption and water vapour absorption), are also controlled through the relaxation of swelling and/or thermal stresses caused by local changes in concentration of bound water and/or temperature [58]. Therefore, further experimental work is needed in order to fully explain the influence of surface pre-treatment on particleboard and OSB sorption processes.

The water penetration depth on the particleboard and OSB panel is presented in Figure 6. It is shown that water penetration depth increased with the surface treatment of OSB panels, which is related to the increase in water absorption of OSB shown in Figure 4. Furthermore, there are no significant differences in the depth of water penetration between the surfaces of treated and untreated particleboard, which also coincides with the results of water absorption of particleboard shown in Figure 4. Moreover, water penetration depth was greater on particleboard than on the OSB panels, regardless of the surface treatment. 

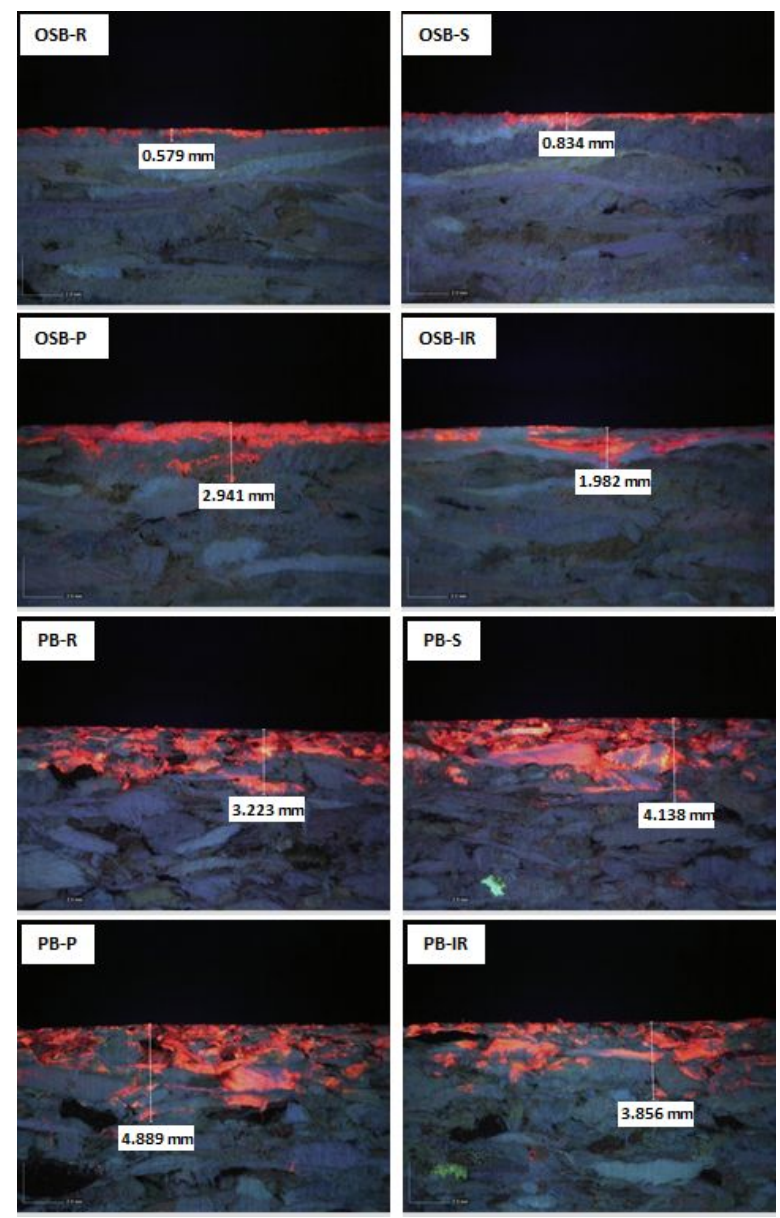

Figure 6. Micrographs of water penetration depth on particleboard and OSB samples at $20 \times$ magnification (PB-R: raw particleboard, PB-S: sanded particleboard, PB-P: re-pressed particleboard, PB-IR: heated particleboard, OSB-R: raw OSB, OSB-S: sanded OSB, OSB-P: re-pressed OSB, and OSB-IR: heated OSB).

\section{Conclusions}

A summary of the results of this research is shown in Table 5 and, based on the obtained results, the following conclusions can be made:

1. Brinell hardness of particleboard and OSB increase after re-pressing. This is most probably due to the densification of outermost layers of examined panels as affected with the pressure and temperature used at re-pressing;

2. Wetting of particleboard and OSB surface with water improved when the surface layer of resin was removed, indicating that with sanding the protective hydrophobic barrier was removed from the panel's surfaces. At the same time, the re-pressing at a temperature of $120^{\circ} \mathrm{C}$ and IR heating at $50^{\circ} \mathrm{C}$ had no significant effect on the wetting of panel surfaces with water, formamide or diiodometane;

3. In addition, sanding reduced surface free energy of particleboard and increased surface free energy of OSB. This can be related to the changes in surface roughness of OSB and particleboard after sanding. More precisely, it can be connected to the appearance of small cavities related to the complete removal of wood-dust resin spots, the presence of which also affected the water absorption;

4. The studied surface treatments increased water absorption and water penetration depth of OSB panels. Moreover, re-pressing had a positive effect on reducing the water vapour absorption of particleboard and OSB. This is due to the removal of protective hydrophobic barrier by sanding, to density increase after re-pressing, and, to some extent, to the reduced hydrophylicity of the outermost layers of individual 
strands on the particleboard and OSB surfaces due to the lignin degradation caused by additional heating of panels surfaces.

Table 5. Summary of the impact of post-manufacture treatments on the studied properties of the surface of particleboard and OSB (R: raw, S: sanded, P: re-pressed, and IR: heated).

\begin{tabular}{|c|c|c|c|c|c|c|}
\hline \multirow{2}{*}{ Properties } & \multicolumn{3}{|c|}{ Particleboard } & \multicolumn{3}{|c|}{ OSB } \\
\hline & S & $\mathbf{P}$ & IR & S & $\mathbf{P}$ & IR \\
\hline Brinell hardness & n.a. & $4_{28.2 \%}$ & n.a. & n.a. & $\boldsymbol{A}_{14.0 \%}$ & n.a. \\
\hline Contact angle-water & $\nabla 66.9 \%$ & $\nabla_{1.5 \%}$ & $\nabla 2.7 \%$ & $\nabla 38.1 \%$ & $\uparrow_{2.1 \%}$ & $\nabla 0.2 \%$ \\
\hline Contact angle-diiodomethane & $\nabla_{100 \%}$ & $\nabla_{28.1 \%}$ & $\nabla_{12.7 \%}$ & $\nabla_{6.45 \%}$ & $\nabla_{13.5 \%}$ & $\nabla 18.5 \%$ \\
\hline Contact angle—formamide & $\nabla_{22.9 \%}$ & $\nabla 9.0 \%$ & ${ }_{18.6 \%}$ & $\nabla 63.3 \%$ & $\uparrow_{13.5 \%}$ & $4_{7.6 \%}$ \\
\hline Surface free energy & $\downarrow_{5.6} \%$ & $\uparrow_{10.3 \%}$ & $\nabla_{3.1 \%}$ & $\uparrow_{107.6 \%}$ & $\varphi_{4.32 \%}$ & $\uparrow_{12.9 \%}$ \\
\hline Roughness- $\mathrm{R} a$ & $40.4 \%$ & 7 $6.5 \%$ & $436.7 \%$ & $\nabla_{23.1 \%}$ & $42.9 \%$ & $\nabla_{23.1 \%}$ \\
\hline Roughness- $\mathrm{Rz}$ & $49.9 \%$ & $\nabla 5.1 \%$ & $4_{35.5 \%}$ & $\nabla_{16.0 \%}$ & $4_{3.7 \%}$ & $\nabla_{23.7 \%}$ \\
\hline Roughness-Rt & $4_{12.9 \%}$ & $\Delta_{2.4 \%}$ & $4_{40.1 \%}$ & $\nabla_{20.7 \%}$ & $\uparrow_{13.3 \%}$ & $\nabla_{22.3 \%}$ \\
\hline Roughness-Rv & $18.8 \%$ & $\uparrow_{1.8 \%}$ & $4_{37.5 \%}$ & $\nabla_{22.4 \%}$ & $\Lambda_{2.9 \%}$ & $\nabla 26.2 \%$ \\
\hline Roughness-Rsk & $\nabla_{44.2 \%}$ & $\nabla_{23.1 \%}$ & $\nabla_{3.8 \%}$ & $\uparrow_{14.0 \%}$ & $\nabla_{23.7 \%}$ & $4_{7.5 \%}$ \\
\hline Roughness-RSm & $\boldsymbol{A}_{15.5 \%}$ & $4_{3.8} \%$ & $4_{38.3 \%}$ & $\nabla_{40.3 \%}$ & $\nabla 25.9 \%$ & $\nabla 35.0 \%$ \\
\hline Water absorption -7 days & $4.5 \%$ & $\nabla_{1.1 \%}$ & $\boldsymbol{4}_{1.2 \%}$ & $4_{42.4 \%}$ & $4_{53.2 \%}$ & $\phi_{>34.6 \%}$ \\
\hline Water vapour absorption-14 days & $\nabla_{21.6 \%}$ & $\nabla_{15.5 \%}$ & $\boldsymbol{A}_{13.3 \%}$ & $43.5 \%$ & $\nabla 20.3 \%$ & $\nabla 10.8 \%$ \\
\hline Water penetration & $\widehat{\top}_{28.4 \%}$ & $4_{51.7 \%}$ & ${ }_{19.7 \%}$ & $4_{57.7 \%}$ & $4_{446.5 \%}$ & 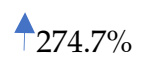 \\
\hline
\end{tabular}

4 Increase in value compared to raw panel. $\downarrow$ Decrease in value compared to raw panel.

Author Contributions: Conceptualization, J.M.; methodology, A.C., V.J.-R., N.Š. and J.M.; investigation, A.C., N.Š. and J.M.; data curation, A.C.; writing-original draft preparation, A.C., V.J.-R., N.Š. and J.M.; writing-review and editing, J.M.; and project administration, J.M. All authors have read and agreed to the published version of the manuscript.

Funding: This research was funded by CROATIAN SCIENCE FOUNDATION and DYNEA AS, grant number PAR 2018.

Data Availability Statement: The data presented in this study are available on request from the corresponding author. The data are not publicly available because this study is a part of on-going research.

Conflicts of Interest: The authors declare no conflict of interest. The funders had no role in the design of the study; in the collection, analyses, or interpretation of data; in the writing of the manuscript, or in the decision to publish the results.

\section{References}

1. Papadopoulos, A.N.; Ntalos, G.A.; Kakaras, I. Mechanical and Physical Properties of Cement-Bonded OSB. Holz Roh Werkst. 2006, 64, 517-518. [CrossRef]

2. Ayrilmis, N. Surface Properties of Oriented Strand Board Coated by Electrostatic Dry Powder Spray Deposition Technique. BioResources 2020, 15, 1521-1530.

3. Branowski, B.; Starczewski, K.; Zabłocki, M.; Sydor, M. Design Issues of Innovative Furniture Fasteners for Wood-Based Boards. BioResourses 2020, 15, 8472-8495. [CrossRef]

4. Timusk, P.C. An Investigation of the Moisture Sorption and Permeability Properties of Mill-Fabricated Oriented Strandboard. Ph.D. Thesis, University of Toronto, Toronto, ON, Canada, 2008; p. 266.

5. Owodunni, A.A.; Lamaming, J.; Hashim, R.; Taiwo, O.F.A.; Hussin, M.H.; Mohamad Kassim, M.H.; Bustami, Y.; Sulaiman, O.; Amini, M.H.M.; Hiziroglu, S. Adhesive Application on Particleboard from Natural Fibers: A Review. Polym. Compos. 2020, 41, 4448-4460. [CrossRef] 
6. Sydor, M.; Majka, J.; Langová, N. Effective Diameters of Drilled Holes in Pinewood in Response to Changes in Relative Humidity. BioResources 2021, 16, 5407-5421. [CrossRef]

7. Kelly, M.W. Critical Literature Review of Relationships Between Processing Parameters and Physical Properties of Particleboard; Forest Products Laboratory: Madison, WI, USA, 1977; p. 70.

8. Tjeerdsma, B.F.; Boonstra, M.; Pizzi, A.; Tekely, P.; Militz, H. Characterisation of Thermally Modified Wood: Molecular Reasons for Wood Performance Improvement. Holz Roh Werkst. 1998, 56, 149-153. [CrossRef]

9. Mitchell, P.H. Irreversible Property Changes of Small Loblolly Pine Specimens Heated in Air, Nitrogen, or Oxygen. Wood Fibre Sci. 1988, 20, 320-335.

10. Carvalho, A.; Zanuncio, A.; Carneiro, A.; da Silva, C.; Erkel, E.; Vital, B. Hydrothermal Treatment of Eucalyptus Strand Particles for Improvement of Oriented Strand Board (OSB) Panels. JTFS 2020, 32, 136-143. [CrossRef]

11. De Melo, R.R.; Muhl, M.; Stangerlin, D.M.; Alfenas, R.F.; Rodolfo Junior, F. Properties of Particleboards Submitted to Heat Treatments. Ciênc. Florest. 2018, 28, 776. [CrossRef]

12. Mendes, R.F.; Júnior, G.B.; de Almeida, N.F.; Surdi, P.G.; Barbeiro, I.N. Effect of Thermal Treatment on Properties of OSB Panels. Wood Sci. Technol. 2013, 47, 243-256. [CrossRef]

13. Ayrilmis, N.; Laufenberg, T.L.; Winandy, J.E. Dimensional Stability and Creep Behavior of Heat-Treated Exterior Medium Density Flberboard. Holz Roh Werkst. 2009, 67, 287-295. [CrossRef]

14. Del Menezzi, C.H.S.; Tomaselli, I. Contact Thermal Post-Treatment of Oriented Strandboard to Improve Dimensional Stability: A Preliminary Study. Holz Roh Werkst 2006, 64, 212-217. [CrossRef]

15. Boonstra, M.J.; Pizzi, A.; Zomers, F.; Ohlmeyer, M.; Paul, W. The Effects of a Two Stage Heat Treatment Process on the Properties of Particleboard. Holz Roh Werkst. 2006, 64, 157-164. [CrossRef]

16. Suchland, O.; Enlow, R.C. Heat Treatment of Exterior Particleboard. For. Prod. J. 1968, 18, $24-28$.

17. Okino, E.Y.A.; Teixeira, D.E.; Del Menezzi, C.H.S. Post-Thermal Treatment of Oriented Strandboard (OSB) Made from Cypress (Cupressus Glauca Lam.). Maderas Cienc. Tecnol. 2007, 9. [CrossRef]

18. Carvalho, A.G.; Mendes, R.F.; Oliveira, S.L.; Mendes, L.M. Effect of Post-Production Heat Treatment on Particleboard from Sugarcane Bagasse. Mater. Res. 2015, 18, 78-84. [CrossRef]

19. Demirbas, A. Mechanisms of Liquefaction and Pyrolysis Reactions of Biomass. Energy Convers. Manag. 2000, 41, 633-646. [CrossRef]

20. Winandy, J.E.; Krzysik, A.M. Thermal Degradation of Wood Fibers during Hot-Pressing of MDF Composites: Part I. Relative Effects and Benefits of Thermal Exposure. Wood Fibre Sci. 2007, 39, 450-461.

21. Hsu, W.E.; Schwald, W.; Schwald, J.; Shields, J.A. Chemical and Physical Changes Required for Producing Dimensionally Stable Wood-Based Composites: Part I: Steam Pretreatment. Wood Sci.Technol. 1988, 22, 281-289. [CrossRef]

22. Repellin, V.; Guyonnet, R. Evaluation of Heat Treated Wood Swelling by Differential Scanning Calorimetry in Relation with Chemical Composition. Holzforschung 2005, 59, 28-34. [CrossRef]

23. H’ng, P.S.; Lee, S.H.; Lum, W.C. Effect of Post Heat Treatment on Dimensional Stability of UF Bonded Particleboard. Asian J. Appl. Sci. 2012, 5, 299-306. [CrossRef]

24. Metsä-Kortelainen, S.; Antikainen, T.; Viitaniemi, P. The Water Absorption of Sapwood and Heartwood of Scots Pine and Norway Spruce Heat-Treated at $170{ }^{\circ} \mathrm{C}, 190^{\circ} \mathrm{C}, 210^{\circ} \mathrm{C}$ and $230^{\circ} \mathrm{C}$. Holz Roh Werkst. 2006, 64, 192-197. [CrossRef]

25. Gupta, R.C.; Singh, S.P.; Nautiyal, S.-N. Studies on Tempering of Phenolic Bonded Particle Board. J. Timber Dev. Assoc. India 1980, $26,16-18$.

26. Gurau, L.; Irle, M. Surface Roughness Evaluation Methods for Wood Products: A Review. Curr. For. Rep. 2017, 3, 119-131. [CrossRef]

27. Sydor, M.; Mirski, R.; Stuper-Szablewska, K.; Rogoziński, T. Efficiency of Machine Sanding of Wood. Appl. Sci. 2021, 11, 2860. [CrossRef]

28. Rolleri, A.; Roffael, E. Surface Roughness of Uncoated Particleboards and Its Relation with the Raw Material, Adhesive and Climatic Conditions. Eur. J. Wood Prod. 2010, 68, 369-372. [CrossRef]

29. Ulker, O. Surface Roughness of Composite Panels as a Quality Control Tool. Materials 2018, 11, 407. [CrossRef]

30. Gurau, L.; Benthien, J.T.; Ohlmeyer, M.; Ayrilmis, N. Effect of Particleboard Density and Core Layer Particle Thickness on Surface Roughness. Drewno. Pr. Naukowe Doniesienia Komun. 2019, 71-83. [CrossRef]

31. Nemli, G.; Ozturk, I.; Aydin, I. Some of the Parameters Influencing Surface Roughness of Particleboard. Build. Environ. 2005, 40, 1337-1340. [CrossRef]

32. Kalaycioglu, H.; Deniz, I.; Hiziroglu, S. Some of the Properties of Particleboard Made from Paulownia. J. Wood Sci. 2005, 51, 410-414. [CrossRef]

33. Hiziroglu, S.; Suzuki, S. Evaluation of Surface Roughness of Commercially Manufactured Particleboard and Medium Density Fiberboard in Japan. J. Mater. Process. Technol. 2007, 184, 436-440. [CrossRef]

34. Nemli, G.; Akbulut, T.; Zekoviç, E. Effects of Some Sanding Factors on the Surface Roughness of Particleboard. Silva Fenn. 2007, 41. [CrossRef]

35. Tabarsa, T.; Ashori, A.; Gholamzadeh, M. Evaluation of Surface Roughness and Mechanical Properties of Particleboard Panels Made from Bagasse. Compos. Part B Eng. 2011, 42, 1330-1335. [CrossRef] 
36. Baharoğlu, M.; Nemli, G.; Sarı, B.; Bardak, S.; Ayrılmıs, N. The Influence of Moisture Content of Raw Material on the Physical and Mechanical Properties, Surface Roughness, Wettability, and Formaldehyde Emission of Particleboard Composite. Compos. Part B Eng. 2012, 43, 2448-2451. [CrossRef]

37. Unsal, O.; Candan, Z.; Buyuksari, U.; Korkut, S.; Babiak, M. Effects of Thermal Modification on Surface Characteristics of OSB Panels. Wood Res. 2010, 55, 51-58.

38. Del Menezzi, C.H.S.; Riberio, R.B.; Sternadt, G.H.; Teixeira, D.E.; Okino, E. Effect of Thermal Post-Treatment on Some SurfaceRelated Properties of Oriented Strandboards. Drv. Industija 2008, 59, 61-67.

39. Hiziroglu, S.; Jarusombuti, S.; Fueangvivat, V. Surface Characteristics of Wood Composites Manufactured in Thailand. Build. Environ. 2004, 39, 1359-1364. [CrossRef]

40. Richter, K.; Feist, W.C.; Mark, T.K. The Effect of Surface Roughness on the Performance of Finishes. For. Prod. J. 1995, 45, 8.

41. Evans, P.D.; Cullis, I. Effect of Sanding and Coating with UV-Cured Finishes on the Surface Roughness, Dimensional Stability and Fire Resistance of Oriented Strandboard. Holz Roh Werkst. 2008, 66, 191-199. [CrossRef]

42. EN 1534 Wood Flooring and Parquet-Determination of Resistance to Indentation-Test Method; The European Committee for Standardization: Brussel, Belgium, 2020.

43. Wålinder, M.E.P.; Gardner, D.J. Acid-Base Characterization of Wood and Selected Thermoplastics. J. Adhes. Sci. Technol. 2002, 16, 1625-1649. [CrossRef]

44. Ström, G.; Fredriksson, M.; Stenius, P. Contact Angles, Work of Adhesion, and Interfacial Tensions at a Dissolving Hydrocarbon Surface. J. Colloid Interface Sci. 1987, 119, 352-361. [CrossRef]

45. Kaelble, D.H. Dispersion-Polar Surface Tension Properties of Organic Solids. J. Adhes. 1970, 2, 66-81. [CrossRef]

46. Software SCA Module SCA 21; DataPhysics: Fiderstadt, Germany, 2006.

47. Blateyron, F. Profile Parameters from ISO 4287. Digital Surf 2020. Available online: https://www.google.com.hk/search?q=P rofile+Parameters+from+ISO+4287\&sxsrf=ALeKk00SISCJ1x90w1Wbtf5W3gwpYKNNuw\%3A1626745064554\&source=hp\&ei =6Cj2YOfjH5LpmAW2yqvgDQ\&iflsig=AINFCbYAAAAAYPY2-PBDXXOX_QSv17fcCf1qQweu9J6_\&oq=Profile+Parameters +from+ISO+4287\&gs_lcp=Cgdnd3Mtd216EANQsJkBWLCZAWDJmwFoAHAAeACAAZEBiAGRAZIBAzAuMZgBAKABAq ABAaoBB2d3cy13aXo\&sclient=gws-wiz\&ved=0ahUKEwjn99fNwfDxAhWSNKYKHTblCtwQ4dUDCAY\&uact=5 (accessed on 13 January 2021).

48. Dos Santos, P.C.; Del Menezzi, C.H.S. Effect of the Densification Process on Properties of Commercial Oriented Strand Boards. Eur. J. Wood Prod. 2018, 76, 1707-1713. [CrossRef]

49. Sydor, M.; Pinkowski, G.; Jasińska, A. The Brinell Method for Determining Hardness of Wood Flooring Materials. Forests 2020, 11, 878. [CrossRef]

50. Lee, S.; Lum, W.; Zaidon, A.; Fatin-Ruzanna, J.; Tan, L.; Mariusz, M.; Chin, K. Effect of Post-Thermal Treatment on the Density Profile of Rubberwood Particleboard and Its Relation to Mechanical Properties. J. Trop. For. Sci. 2017, 13, 93-104.

51. Gérardin, P.; Petrič, M.; Petrissans, M.; Lambert, J.; Ehrhrardt, J.J. Evolution of Wood Surface Free Energy after Heat Treatment. Polym. Degrad. Stab. 2007, 92, 653-657. [CrossRef]

52. Akgül, M.; Korkut, S.; Çamlibel, O.; Candan, Z.; Akbulut, T. Wettability and Surface Roughness Characteristics of Medium Density Fiberboard Panels from Rhododendron (Rhododendron Ponticum) Biomass. Maderas Cienc. Tecnol. 2012, 14, 185-193. [CrossRef]

53. de Meijer, M.; Haemers, S.; Cobben, W.; Militz, H. Surface Energy Determinations of Wood: Comparison of Methods and Wood Species. Langmuir 2000, 16, 9352-9359. [CrossRef]

54. Bardak, S.; Nemli, G.; Sari, B.; Baharoglu, M.; Zekovic, E. Manufacture and Properties of Particleboard Composite From Waste Sanding Dusts. High Temp. Mater. Process. 2010, 29, 159-168. [CrossRef]

55. Pędzik, M.; Stuper-Szablewska, K.; Sydor, M.; Rogoziński, T. Influence of Grit Size and Wood Species on the Granularity of Dust Particles during Sanding. Appl. Sci. 2020, 10, 8165. [CrossRef]

56. Kačik, F.; Kačikova, D.; Bubenikova, T. Spruce Wood Lignin Alterations after Infrared Heating at Different Wood Moistures. Cellul. Chem. Technol. 2006, 40, 643-648.

57. Christensen, G.N.; Kelsey, K.E. The rate of sorption of water vapor by wood. Holz Roh Werkst. 1959, 17, 178-188. [CrossRef]

58. Engelund, E.T.; Thygesen, L.G.; Svensson, S.; Hill, C.A.S. A Critical Discussion of the Physics of Wood-Water Interactions. Wood Sci. Technol. 2013, 47, 141-161. [CrossRef] 